\title{
QUELLINUS SCHOOL AND ARCHITECT COSMAN CITROEN
}

\author{
SANTOSO, Joko Triwinarto \\ Department of Architecture, Faculty of Engineering \\ Brawijaya University, Malang - INDONESIA \\ Email: jokotris@ub.ac.id
}

\begin{abstract}
This article describes the Quellinus School in Amsterdam where the Dutch architect Cosman Citroen (1881-1935), an advisory architect of the Municipality of Surabaya, studied architecture. It starts from the origin of the school in 1876 until around 1904. From the analysis, it can be identified the teachers who trained him and what subjects he learned during his study.
\end{abstract}

Keywords: Quellinus School, C. Citroen, Surabaya, Amsterdam, architectural education.

\section{INTRODUCTION}

Background of an architectural education in which an architect studied, contributes in great quantities on his way of thinking and work characteristics, in particularly in his early period of his career. One of the architects who cannot be separated from architectural development during the twentieth-century Dutch colonial period in Surabaya, East Java, Netherlands Indies is the Dutch architect Cosman Citroen (18811935). He had an important role due to his position as an architectural advisor of the Municipality of Surabaya in the period of 1915-1930 and also support of G.J. Dijkerman, the Major of the city from 1920 to 1929. In a wider scope, he was one of the remarkable architects in the Netherlands Indies at the time.

Before his arrival to this city, Citroen lived in Amsterdam where he studied and afterwards worked for a while. He learned architecture at the KunstNijverheid-Teekenschool (Arts, Crafts and Drawings School) "Quellinus" in Amsterdam (Zeeuw, 2001). This is the school where his talent for pen drawing was developed (Anonymous, 1925). Unfortunately, no previous study could reveal who were his teachers and what subjects he learned in the school. This article tries to answer those questions.

\section{MATERIAL AND METHODS}

To answer the above questions, the first step is to disclose a history of the Quellinus School. From here, it will be known curriculums which had been ever implemented and teachers who had taught. This article uses sources written by Martis (1980). Supporting materials are obtained from websites.

In the meanwhile, to trace when Citroen studied in the school, the author departed from his member- ship in Genootschap Architectura et Amicitia (Association of Architectura et Amicitia), a Dutch architectural association based in Amsterdam that aims to bring together architects and individuals from related disciplines to exchange information with one another and to continue to inspire each other by means of excursions, lectures and exhibitions (Anonymous, 2013). Schilt and van der Werf (1992) wrote history of this association in their book, including a list of its members. Furthermore, with the assumption that Citroen became a member shortly or immediately after his graduation, and also taking into account the duration of the study in the Quellinus School, it can be determined since and until when Citroen studied at the school.

From the both approaches can be known who had taught Citroen and what subjects he obtained in the Quellinus School.

\section{ORIGIN OF THE QUELLINUS SCHOOL 1876-1879}

The Quellinus School was officially opened on 8 September 1879, although the school had been in existence since 15 May 1876. The idea to establish the school came about when P.J.H. Cuypers, architect of the Rijksmuseum (National Museum) in Amsterdam, wrote a letter dated 12 September 1879 to the Minister of Internal Affairs Victor de Stuers about the shortage of designers and artists, especially sculptors and ornament workers, in the northern provinces. At the time, the demand for such art workers was met by inviting workers from the southern provinces. Then, in his second letter dated 9 April 1877, Cuypers repeated the request of his previous letter and proposed to assign E.C.E. Colinet (1844-1890) to manage the young artists involved in working on the museum buildings (Martis, 1980). 
Colinet was a Belgian sculptor assisting Cuypers at the National Museum. In an article in the Algemeen Handelsblad dated 7 November 1878, he explained that in order to solve the shortage problem of decorative sculptors, Cuypers would propose to educate the art workers, although he himself had had workshops in Roermond since 1858. Close relationships between the duo Cuypers-Colinet and the Departement Amsterdam van de Maatschappij ter Bevordering van Nijverheid (Amsterdam Department of Society for Advancement of Industry) contributed significantly to the establishment of the Quellinus School. Colinet hoped the plan to establish an independent school would be successful (Martis, 1980).

A short report in the Algemeen Handelsblad dated 20 December 1878 mentioned that a number of prominent figures from the city met with the board of the Amsterdam Department of Society for Advancement of Industry to discuss the founding of a secondary school for art industry. At the end of the meeting, participants agreed to prepare a commission to take further steps. Finally, an association was established and named De Vereeniging "Quellinus" (Association of Quellinus) to promote art education. The name "Quellinus" was given based on a request from Colinet to the association (Martis, 1980). Artus Quellinus (1609-1668) was the sculptor responsible for the majority of the sculptures in Amsterdam City Hall (Anonymous, 2008).

Statutes of the Quellinus Association declared that the head of Amsterdam Department of Society for Advancement of Industry was automatically to become a member of the association. The association's financial resources came from grants and donations, from members and interested parties, annual contributions, subsidies from the government, and also in part from revenue at the workshops. Government grants were awarded on the condition that:

- the regulations, curriculum, timetable, appointment of teachers and classrooms were approved by the Ministry of Internal Affairs;

- the budget for the following year and the accounts for the previous year were presented to the Minister for approval;

- an annual report was created and sent to the Minister in accordance with the plan; and

- the school would be always accessible to the civil servants designated by the Minister (Martis, 1980).

On 15 May 1879, the Quellinus School was opened in Cuypers' former home and workshop at Voldestraat 9, Amsterdam. On 1 May 1882, the school moved to a new building at Frans Halsstraat 14, Amsterdam (Martis, 1980).

\section{EDUCATION UNTIL 1890}

At the outset, the Quellinus School was characterized as an art school emphasizing practical work and exercises in workshops, more than was required in an art academy. In the first year, the students received basic training in art, mostly in theoretical classes. In the second and subsequent years, they focused on specific areas based on their interests. Primary areas of study were drawing, modelling, sculpturing and decorative painting (Martis, 1980).

The first curriculum did not change until 1883 when the duration of study was reduced from five years to three because of complaints and the assumption that three years were sufficient for a secondary school based on the level of experience. In short, education was defined as a rational and systematic elementary education, seen in its emphasis on both ornament drawing and natural drawing, i.e. from drawing from wire and block models to drawing from plaster models (Martis, 1980).

At the beginning of the 1886/1887 academic year, the Minister advised on regulations, curriculum and timetables for the Quellinus School to W.B.G. Molkenboer, Director of the Rijksnormaalschool (State Teachers' College) in Amsterdam, an inspector for drawing and industrial schools subsidized by the government. After consultation with the board and teachers of the Quellinus School in December 1886, Molkenboer informed the board that the amendment had resulted in a comprehensive plan and timetable that had to be approved by the Minister. An important point was that the school should have three departments, like those in the Rijksnormaalschool voor Teekenonderwijzers (State Teachers' College for Drawing Teachers), i.e. hand drawing (A), straightline or architectural drawing (B) and modelling (C). Another point was the number of hours should be extended, especially in the afternoon (Martis, 1980).

Colinet resigned in July 1883 and his position was occupied by August van Delden who in 1882 became a teacher of architectural drawing, ornament and perspective drawing. He also came from Cuypers' studio. Before taking charge of the Quellinus School, Van Delden was a superintendent for construction of the National Museum. He filled the position until February 1887 when he was appointed director of the Koninklijke Academie van Beeldende Kunsten (Royal Academy of Fine Arts) in The Hague; his teaching position in Amsterdam was taken over by H.P Berlage and J.F. Klinkhamer. The 
management of education was entrusted to a committee consisting of three members of the board and the responsibilities of the administrator were substantially expanded (Martis, 1980).

In the 1888/1889 academic year, Bart van Hove, who had been a teacher of modelling and anatomy since 1883, was appointed as the new director until 1 December 1900. During his leadership, the regulations were developed more clearly and more specifically and the curriculum was better defined and organized (see Table 1) (Martis, 1980).

Theoretical education was offered within the three departments. Courses on projection and perspective, as both sustained theory and the basis for training, were understood as the rational education to explain the appearance of objects and to support the drawings. Instruction in freehand drawing was also strongly rational and systematic: in the first year the students were trained first in line drawing and then in wall plates; in freehand with chalk on blackboards and then onto paper. If they had acquired enough skill, the students drew wire, block and lathwork prototypes and continued on to draw simple objects from everyday life. Additionally, in the first year, the students drew plaster casts made from main ornaments and parts of the body (Martis, 1980).

In the first year, 24 of 39 course hours were the same for each student. The time remaining was dedicated to painting on flat ornaments and plate models in Department A, drawing of ornaments on a large scale in Department B and the clay copying of plaster models of ornaments and roofs of simple wood and stone ornaments in Department C. In the second and third years, the number of course hours was equal in each department. Compared to the first year programme, the most important changes were the omission of straight-line drawing courses and an increase in the number of specific courses related to each of the departments chosen by the students. Straight-line drawing was only continued in Department $\mathrm{B}$ as architectural drawing. In the second and third years, hand drawing on plaster casts was taught twelve hours per week in all departments, mainly for building components in the second year and ornaments, heads and bodies in the third year. Overall, 22 of the 39 hours per department were different, dedicated to painting in Department A, architectural drawing and large-scale ornament drawing in Department $\mathrm{B}$ and sculpture and modelling in Department $\mathrm{C}$ (Martis, 1980).

\section{EDUCATION IN 1890 UNTIL AROUND 1900}

In 1890 the Quellinus School extended its education by opening Department D (Lithography). The number of students in this department increased

Table 1. Distribution of Different Subjects in Class Hours per Week in the Quellinus School 1887-1890

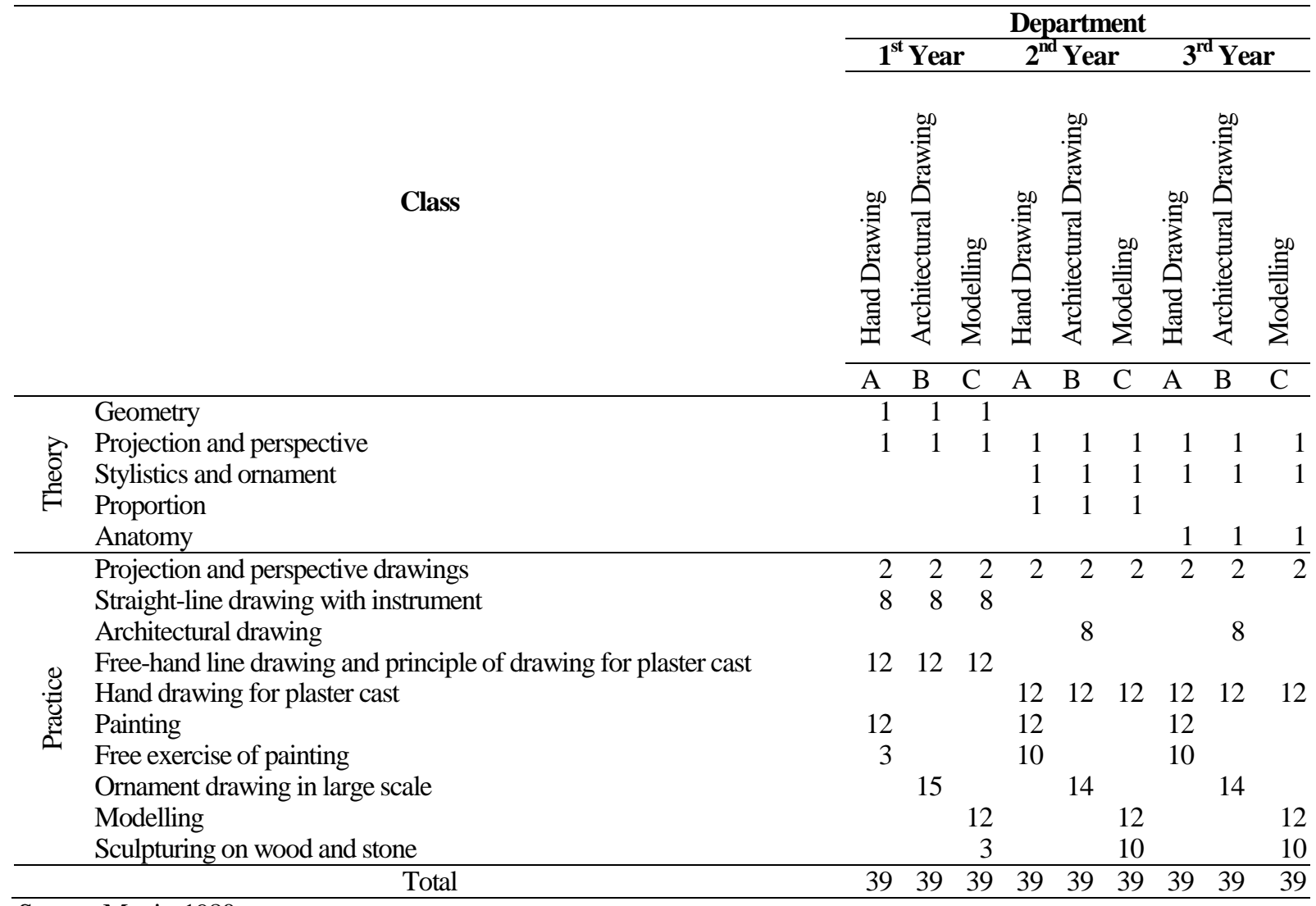

Source: Martis, 1980. 
Table 2. Distribution of Different Subjects in Class Hours per Week in the Quellinus School ca. 1900

\begin{tabular}{|c|c|c|c|c|c|c|c|c|c|c|c|c|c|c|c|c|}
\hline & \multirow{4}{*}{ Class } & \multicolumn{15}{|c|}{ Department } \\
\hline & & \multicolumn{5}{|c|}{$1^{\text {st }}$ Year } & \multicolumn{5}{|c|}{$2^{\text {nd }}$ Year } & \multicolumn{5}{|c|}{$3^{\text {rd }}$ Year } \\
\hline & & 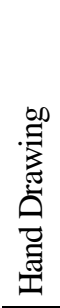 & 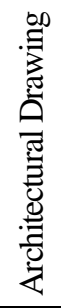 & $\frac{\stackrel{0}{0}}{\stackrel{\Xi}{\bar{d}}}$ & 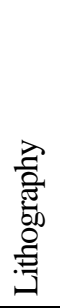 & 总 & 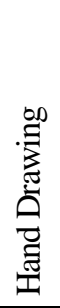 & 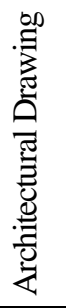 & : & 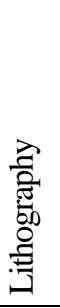 & 莺 & 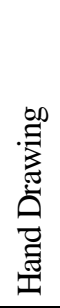 & 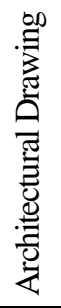 & $\frac{\infty}{\stackrel{0}{0}}$ & 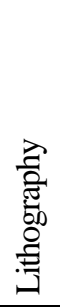 & 总 \\
\hline & & $\mathrm{A}$ & $\mathrm{B}$ & $\mathrm{C}$ & $\mathrm{D}$ & $\mathrm{E}$ & $\mathrm{A}$ & $\mathrm{B}$ & $\mathrm{CH}$ & $\mathrm{D}$ & $\mathrm{E}$ & $\mathrm{A}$ & $\mathrm{B}$ & $\mathrm{C}$ & $\mathrm{D}$ & $\mathrm{E}$ \\
\hline \multirow{5}{*}{$\begin{array}{l}\text { Dें } \\
\text { E } \\
\text { E }\end{array}$} & Geometry & 1 & 1 & 1 & 1 & 1 & & & & & & & & & & \\
\hline & Projection and perspective & 1 & 1 & 1 & & & 1 & 1 & 1 & 1 & 1 & 1 & 1 & 1 & 1 & 1 \\
\hline & Stylistics and ornament & & & & & & 1 & 1 & 1 & 1 & 1 & 1 & 1 & 1 & 1 & 1 \\
\hline & Proportion & & & & & & 1 & 1 & 1 & 1 & 1 & & & & & \\
\hline & Anatomy & & & & & & & & & & & 1 & 1 & 1 & 1 & 1 \\
\hline \multirow{13}{*}{ 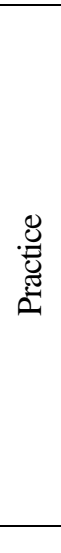 } & Projection and perspective drawings & 2 & 2 & 2 & 2 & 2 & 2 & 2 & 2 & 2 & 2 & 2 & 2 & 2 & 2 & 2 \\
\hline & Straight-line drawing with instrument & 8 & & 4 & 8 & 8 & & & & & & & & & & \\
\hline & Architectural drawing & & 8 & & & & & 18 & & & & & 18 & & & 2 \\
\hline & $\begin{array}{l}\text { Free hand line drawing and principle of drawing } \\
\text { for plaster cast }\end{array}$ & 12 & 12 & 12 & 12 & 12 & & & & & & & & & & \\
\hline & Hand drawing for plaster cast & & & & & & 12 & 12 & 12 & 10 & 10 & 12 & 12 & 12 & 12 & 12 \\
\hline & Painting & 12 & & & & & 22 & & & & & 22 & & & & \\
\hline & Free exercise of painting & 3 & & & & & & & & & & & & & & \\
\hline & Ornament drawing in large scale & & 15 & & 15 & 11 & & 4 & & & 2 & & 4 & & & 2 \\
\hline & Modelling & & & 12 & & & & & 12 & & & & & 12 & & \\
\hline & Sculpturing on wood and stone & & & 7 & & & & & 10 & & & & & 10 & & \\
\hline & Furniture drawing & & & & & 4 & & & & & 20 & & & & & 20 \\
\hline & Drawing on stone & & & & & & & & & 22 & & & & & 22 & \\
\hline & Total & 39 & 39 & 39 & 38 & 38 & 39 & 39 & 393 & 37 & 37 & 39 & 39 & 39 & 39 & 39 \\
\hline
\end{tabular}

Source: Martis, 1980.

dramatically over the years. At the same time, Department E (Furniture) proved less viable, and after 1893 no new reports were made (Martis, 1980).

The curriculum did not change noticeably until around 1900. The number of class hours in the first year was reduced from 24 to 16 hours per week. Starting in the first year, architectural drawing was taught in Department B and courses on sculpture were offered in Department $\mathrm{C}$ for four hours per week. This trend was noticeable in the second and third years. The course hours for each department were increased across the board (see Table 2) (Martis, 1980).

After 1900, a new Quellinus School director, C.W. Nijhoff, executed important changes. Starting from 1899 he was a teacher of courses on architectural drawing and style and ornament theories. Very probably, in his leadership the school extended study duration from three years to four years. In part, the changes were the result of a personal conflict between Bart van Hove and C. Stroo who was working at the school from 1880, finally resigning on 1 September 1901. This resignation gave the board the opportunity to restructure the education. The task of Stroo was split between two new teachers: $T$. Tjeerde for nature and ornament drawing for the first grade and H.C. Elzinga for projection geometry and perspective drawing (Martis, 1980).

In the 1901 curriculum, these courses were defined as decorative drawings related to architectural forms, both exterior and interior, and applied to stone, wood, metal, etc. Now, free-hand line drawing and hand drawing was called natural drawing which was taught 12 hours per week in all departments for three years. According to the 1901 curriculum, teaching in natural drawing was still very systematic. It started in the first year with surface drawing, followed by drawing on wire and block models, drawing objects from our environment, related to the form of block models and drawings for simple ornamental forms (plaster models). The curriculum concluded with drawings of the human figure in the third year (Martis, 1980). In subsequent development, the Quellinus School extended the study period from 3 years to 4 years but there is no sources mention when 
the change occurs. In the fourth year, the students practiced what they learned in the previous three years.

Table 3. Teachers of the Quellinus School 1896-1904

\begin{tabular}{|c|c|c|c|c|c|c|c|c|}
\hline \multirow[b]{2}{*}{ Teacher } & \multicolumn{8}{|c|}{ Academic Year } \\
\hline & $\underset{\infty}{\stackrel{\infty}{\infty}}$ & $\frac{\infty}{\stackrel{\infty}{\infty}}$ & $\begin{array}{l}\stackrel{\infty}{\infty} \\
\stackrel{\infty}{\infty}\end{array}$ & $\frac{8}{\delta}$ & $\frac{\bar{\delta}}{\delta}$ & $\frac{\text { }}{\stackrel{\S}{\Xi}}$ & $\frac{\text { }}{\delta}$ & $\frac{d}{\stackrel{\delta}{\S}}$ \\
\hline
\end{tabular}

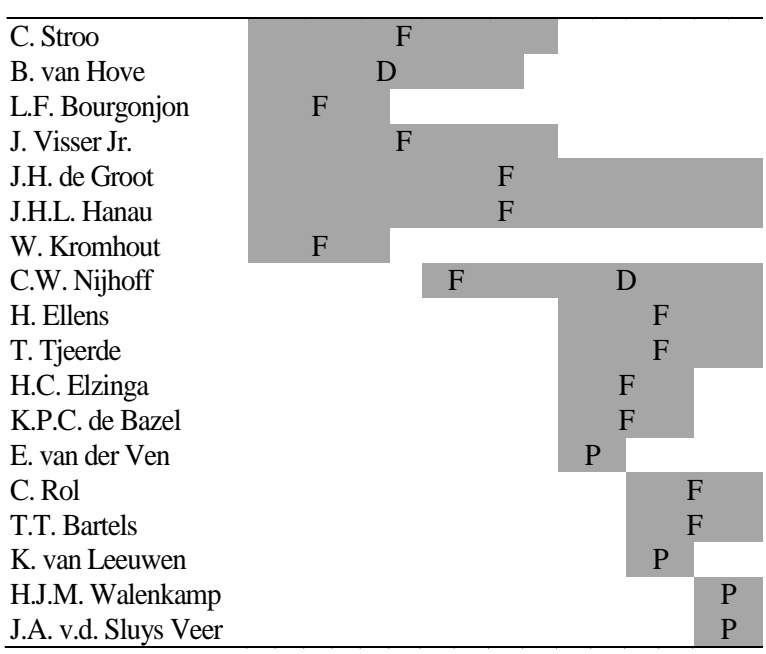

Source: Martis, 1980.

Note: $\mathrm{D}=$ Director, $\mathrm{F}=$ Full-time teacher, $\mathrm{P}=$ Part-time teacher
During the course, the school could not train the students as architectural draftsmen. In practice, their knowledge of building construction was not sufficient. They could complement their studies after leaving the Quellinus School and two years of practice by attending evening courses, for example classes held at the Industrieschool van de Maatschappij voor den Werkenden Stand (Industrial School of the Society for Working State), or the department of Voortgezet en Hooger Bouwkunst Onderricht (Further and Higher Achitectural Education) of the Association of Architectural et Amicitia (Martis, 1980).

\section{CITROEN IN THE QUELLINUS SCHOOL}

No sources mention the exact dates when Citroen studied at the Quellinus School. However, based on the dates of his membership (1902-1907) in the Association of Architectura et Amicitia, his activities during and after his membership in this association (Santoso, 2011), the duration of his Quellinus School education, and Citroen's age, he probably became a student in 1898/1899-1901/1902. During this period, teachers employed by the school were: C. Stroo, B. van Hove, L.F. Bourgonjon, J. Visser Jr., J.H. de Groot, J.H.L. Hanau, W. Kromhout, C.W. Nijhoff, H. Ellens, T. Tjeerde, H.C. Elzinga, K.P.C. de Bazel, E. van der Ven.

Table 4. Classes Attended by Citroen and His Teachers in the Quellinus School (1897/1898-1901/1902)

\begin{tabular}{|c|c|c|c|c|c|}
\hline \multirow[b]{2}{*}{ Class } & \multirow[b]{2}{*}{ Subject } & \multicolumn{4}{|c|}{ Teacher } \\
\hline & & $\begin{array}{c}1^{\text {st }} \text { Year } \\
1898 / 1899\end{array}$ & $\begin{array}{c}2^{\text {nd }} \text { Year } \\
1899 / 1900\end{array}$ & $\begin{array}{c}3^{\text {rd }} \text { Year } \\
1900 / 1901\end{array}$ & $\begin{array}{c}4^{\text {th }} \text { Year } \\
1901 / 1902\end{array}$ \\
\hline \multirow{5}{*}{$\stackrel{\overparen{B}}{8}$} & Geometry & $*$ & - & - & \multirow{10}{*}{$\begin{array}{l}\text { K.P.C. de Bazel, } \\
\text { H.C. Elzinga, C.W. } \\
\text { Nijhoff*** }\end{array}$} \\
\hline & Projection and perspective & $*$ & $* *$ & ** & \\
\hline & Stylistics and ornament & - & C.W. Nijhoff & C.W. Nijhoff & \\
\hline & Proportion & - & $* *$ & - & \\
\hline & Anatomy & - & - & B. van Hove & \\
\hline \multirow{5}{*}{ 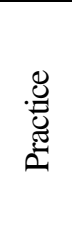 } & Projection and perspective drawings & C. Stroo & C. Stroo & C. Stroo & \\
\hline & Architectural drawing & W. Kromhout & C.W. Nijhoff & C.W. Nijhoff & \\
\hline & $\begin{array}{l}\text { Free hand line drawing and principle } \\
\text { of drawing for plaster cast }\end{array}$ & $*$ & - & - & \\
\hline & Hand drawing for plaster cast & - & ** & $* *$ & \\
\hline & Ornament drawing in large scale & C. Stroo & C. Stroo & C. Stroo & \\
\hline
\end{tabular}

Note:

Determination of 'who teaches what' cannot be decided due to lack of information.

* : one of the following teachers gave lessons in a related class: B. van Hove, L.F. Bourgonjon, J. Visser Jr., J.H. de Groot, J.H.L. Hanau.

** : one of the following teachers gave lessons in a related class: B. van Hove, J. Visser Jr., J.H. de Groot, J.H.L. Hanau.

***: determination of teachers in this position is based on the following reasons:

- the fourth year is the time when the architectural students practice what they have learned in the previous three years so teachers at this level should be professional architects (K.P.C. de Bazel and H.C. Elzinga).

- Although C.W. Nijhoff was not an architect, he was the director of the Quellinus School in that period and thus responsible for the quality of graduates. 
From Table 2, Table 3 and explanation in the previous parts as related to the period of Citroen's education, the following table can be deduced:

\section{CONCLUSION}

From the above explanation, it can be concluded that Citroen was taught, at least, by C. Stroo, C.W. Nijhoff, B. van Hove, W. Kromhout, K.P.C. de Bazel and H.C. Elzinga. The last three are the professional architects so that it can be presumed that their ideas and works influenced on some of Citroen's designs, especially in the early period of his career.

Subjects Citroen learned in the Quellinus School were geometry, projection and perspective, stylistics and ornaments, proportion and anatomy for theoritical classes, while in the practical ones he attended classes for projection and perspective drawings, architectural drawing, free hand line drawing and principle of drawing for plaster cast, hand drawing for plaster cast and ornament drawing in large scale. Therefore, it can be understood that he was adept at drawing with pen.

\section{ACKNOWLEDGEMENT}

This article is a part of a research funded by Ford Foundation through International Fellowships Program (IFP) scheme.

\section{REFERENCES}

Anonymous. (1925). De Architectuur-Tentoonstelling te Batavia, Indisch Bouwkundig Tijdschrift, 28(24), 273-275.

Anonymous. (2008). http://www.kunstbus.nl/kunst/ rietveld-academie.html (accessed 1 October 2013).

Anonymous. (2013). http://nl.wikipedia.org/wiki/ Architectura_et_Amicitia (accessed 8 October 2013)

Martis, Adi. (1980). Het Ontstaan van het Kunstnijverheidsonderwijs in Nederland en de Geschiedenis van de Quellinusschool te Amsterdam (1879-1924), Martis, Adi (ed.). Nederlands Kunsthistorisch Jaarboek 1979, 30: Kunstonderwijs in Nederland, Haarlem Fibula-van Dishoeck, 79-171.

Santoso, Joko Triwinarto. (2011). Association of Architectura et Amicitia and Dutch Architect C. Citroen. Journal of Basic and Applied Scientific Research, 1(9), 1163-1168.

Schilt, Jeroen and Van der Werf, Jouke. (1992). Genootschap Architectura et Amicitia, Rotterdam, Uitgeverij 010.

Zeeuw, Wouter de. (2001). Cosman Citroen 18811935, typescript, Rotterdam, Nederlands Architectuurinstituut. 